Article

\title{
Chemical Compounds and Bioactivity of Aqueous Extracts of Alibertia spp. in the Control of Plutella xylostella L. (Lepidoptera: Plutellidae)
}

Lucas L. S. Peres ${ }^{1}$, Ana I. Sobreiro ${ }^{1}$, Irys F. S. Couto ${ }^{1}$, Rosicléia M. Silva ${ }^{1}$, Fabricio F. Pereira ${ }^{2}$, Silvia C. Heredia-Vieira ${ }^{3}$, Claudia A. L. Cardoso ${ }^{3}$, Munir Mauad ${ }^{4}$, Silvana P. Q. Scalon ${ }^{4}$, Sandra S. Verza ${ }^{5, *}$ and Rosilda M. Mussury ${ }^{1, *}$

1 Laboratory of Insect-Plant Interaction, Faculty of Biological and Environmental Sciences, Federal University of Grande Dourados, Highway Dourados-Itahum, km 12, Dourados 79804-970, Mato Grosso do Sul, Brazil; lucaslsperes@gmail.com (L.L.S.P.); bel_sobreiro@hotmail.com (A.I.S.); irys.ento@gmail.com (I.F.S.C.); rosi_girs@hotmail.com (R.M.S.)

2 Laboratory of Biological Control, Faculty of Biological and Environmental Sciences,

Federal University of Grande Dourados, Highway Dourados-Itahum, km 12, Dourados 79804-970, Mato Grosso do Sul, Brazil; fabriciofagundes@ufgd.edu.br

3 Laboratory of Chemistry, State University of Mato Grosso do Sul, Highway Dourados-Itahum, km 12, Dourados 79804-970, Mato Grosso Do Sul, Brazil; silviacristina_85@hotmail.com (S.C.H.-V.); claudia@uems.br (C.A.L.C.)

4 Laboratory of Vegetables Production, Faculty of Agricultural Sciences, Federal University of Grande Dourados, Highway Dourados-Itahum, km 12, Dourados 79804-970, Mato Grosso Do Sul, Brazil; munirmauad@ufgd.edu.br (M.M.); silvanascalon@ufgd.edu.br (S.P.Q.S.)

5 Laboratory of Social Insects-Pest, Department of Vegetal Production, Phytosanitary Defense, Faculty of Agronomic Sciences, São Paulo State University, Street José Barbosa de Barros, 18610-307, Botucatu, São Paulo 18610-307, Brazil

* Correspondence: sandraverza@yahoo.com (S.S.V.); mussuryufgd@gmail.com (R.M.M.)

Academic Editor: Angel Guerrero

Received: 7 August 2017; Accepted: 14 November 2017; Published: 22 November 2017

\begin{abstract}
Successive applications of insecticides to control Plutella xylostella L. (Lepidoptera: Plutellidae) have resulted in the emergence of resistant populations of this insect. A novel control measure for this target insect could be the use of botanical insecticides derived from plant tissues. Hence, we experimentally tested aqueous extracts of Alibertia edulis (Rich.), Alibertia intermedia (Mart.), and Alibertia sessilis (Vell.) K. Schum. found in the Brazilian savannah in order to investigate their potential to disrupt the life cycle of $P$. xylostella. Aqueous extracts of the leaves of A. intermedia and $A$. sessilis negatively affected the development of $P$. xylostella in all stages of the life cycle, prolonging the larval stage and causing mortality in the larval or pupal stages. Treatments with A. intermedia and A. sessilis extracts caused the lowest fecundity and the number of hatched larvae. The harmful effects of these aqueous extracts on the life cycle of $P$. xylostella may be attributable to the flavonoids and other phenolic compounds present in A. intermedia and A. sessilis. These aqueous botanical extracts are low in toxicity when compared to non-aqueous pesticides, and may emerge as an effective approach for control of populations of $P$. xylostella.
\end{abstract}

Keywords: Alibertia edulis; Alibertia intermedia; Alibertia sessilis; flavonoid; phenolic compounds; Plutella xylostella 


\section{Introduction}

Plutella xylostella (Linnaeus, 1758) (Lepidoptera: Plutellidae), popularly known as the diamondback moth (DBM), is one of the causative agents of brassica damage [1]. Every year, this species causes in excess of $\$ 1$ billion worth of damage worldwide [2]. This is a consequence of the high feeding rates of this insect during the larval period, which can result in significant crop losses [3].

Pesticide application is still the preferred method of farmers to control damaging insect populations [4]. However, P. xylostella has developed resistance to many synthetic insecticides because of its high fertility, tendency towards overlapping generations, genetic plasticity, and, in particular, selection pressure from the use of various insecticides. The application of pesticides, in some years has, nevertheless, been shown to be ineffective in the control of P. xylostella, even after 15 to 20 applications during a crop cycle [5-7]. Pesticide use is particularly common due to its practicality, speed, and efficiency in population control [4]; however, its use can select more resistant individuals [8], thereby exacerbating the problem. Therefore, a number of studies have focused on the control of this insect, ranging from those involving the genes responsible for the production of saponins [9] and proteins [10], to microbial essays [11] and the use of insecticidal plants [8,12]. The use of botanical insecticides represents an interesting alternative to control insects. These insecticides can be prepared from locally available plants [8], have an advantageous cost/benefit ratio [12], and have low toxicity $[10,13,14]$. Several plant species have been examined to evaluate their insecticidal effect, since they may offer higher selectivity [6,7], lower toxicity to non-target organisms [4], local availability, low resistance, and low cross-resistance due to their natural complexes [12,13]. Studies conducted by Amoabeng et al. [12], which assessed the cost/benefit ratio of using plants to control insects, have revealed that botanical insecticides might differ in the level of pest control and beneficial cost when compared with conventional insecticides. However, these biopesticides are easily produced from available naturally-growing plants.

Insecticidal plants can inhibit insect feeding, chitin biosynthesis, and oviposition; reduce intestinal motility, fecundity, and longevity; interfere with ecdysone synthesis; deform both pupae and adults; sterilize individuals; and kill both immature and adult individuals $[15,16]$.

There have been numerous studies on the insecticidal potential of plants [17-19]. Plants in the Rubiaceae family, widely distributed in the Brazilian savannah, have insecticidal properties in addition to their economic relevance. The Rubiaceae family is characterized by the presence of several classes of substances, including phenolic compounds [20,21]. Flavonoids and phenolic and polyphenol acids are among the most prominent [22], in addition to caffeic acids in the Alibertia genus [23,24]. Furthermore, the presence of iridoids [25], alkaloids [26], anthraquinones [27], lignones [28], flavonoids, phenolic derivatives, triterpenes, and diterpenes [20] have all been reported in the literature.

The leaf and root extracts of Palicourea St. Hill have been demonstrated to be toxic to adults of Aetelion sp. (Hemiptera: Aetalionidae), possibly due to the presence of monofluoroacetic acid that interferes with the Krebs cycle and decreases cellular respiration [29]. Palicourea marcgravii St. Hill. has been shown to be efficient in causing mortality of Aphis spiraecola Patch. (Hemiptera: Aphididae). This is probably attributable to the high concentration of monofluoroacetic acid and/or fluoroacetate that, acting synergistically with other compounds, induces a greater toxicity [30]. Catunaregam spinosa (Thunb.) Tirveng. contains triterpenoid saponins with antifeedant activities against P. xylostella [31].

Other botanical families that also show insecticidal activity are the following: Meliaceae, Annonaceae, Asteraceae, Canellaceae, Lamiaceae, Rutaceae [32], Euphorbiaceae, Leguminosae, and Solanaceae [8].

In this study, we tested the following hypotheses: (i) the aqueous extracts of native plants from the Brazilian savannah (Alibertia spp.) affect the development of P. xylostella; (ii) there are morphological changes in insects when in contact with the aqueous extracts; and (iii) Alibertia spp. presents a great potential as insecticidal plant. Given the few studies and potential of the members of the Rubiaceae family, the present study investigated the effect of aqueous extracts of Alibertia edulis, Alibertia intermedia, and Alibertia sessilis on the biological cycle of P. xylostella. 


\section{Materials and Methods}

\subsection{Rearing of Plutella xylostella}

The larvae and pupae of $P$. xylostella were collected from cabbage plantation areas in the cities of Dourados $\left(22^{\circ} 13^{\prime} 16^{\prime \prime} \mathrm{S} 54^{\circ} 48^{\prime} 20^{\prime \prime} \mathrm{W}\right)$ and Itaporã $\left(22^{\circ} 45^{\prime} 6^{\prime \prime} \mathrm{S} 54^{\circ} 47^{\prime} 20^{\prime \prime} \mathrm{W}\right)$, both in the state of Mato Grosso do Sul. The collected P. xylostella were reared at the Insect-Plant Interaction Laboratory of the Faculty of Biological and Environmental Sciences at the Federal University of Grande Dourados (UFGD), Mato Grosso do Sul, Brazil. Individuals were maintained under constant temperature $\left(25 \pm 2{ }^{\circ} \mathrm{C}\right)$ and relative humidity $(55 \% \pm 5 \%)$.

The pupae were placed in transparent plastic cages until the adults emerged. Adults were fed with a $10 \%$ honey solution, and were provided with an oviposition substrate of cabbage discs measuring $8 \mathrm{~cm}$ in diameter placed on moist filter paper.

After oviposition, the leaves holding the eggs were placed in sterile plastic containers measuring $30 \mathrm{~cm}$ in length, $15 \mathrm{~cm}$ in width, and $12 \mathrm{~cm}$ in height. Once hatched, the larvae remained in this container until reaching the pupal stage. The larvae were fed on leaves of organic cabbage (Brassica oleracea var. acephala DC) that were first treated with 5\% sodium hypochlorite solution and then washed in tap water.

Young cabbage leaves, located in the third and fourth node, were collected from plants that had 90 days of growth in the organic garden of the UFGD. Healthy cabbage leaves were placed with the adaxial face against the plastic container. The larvae were placed on the abaxial face, and then covered with another cabbage leaf that was oriented with the abaxial face covering them. This procedure was repeated daily or when the leaves wilted, whichever occurred first, and continued until pupae formation [33] (Figure 1).

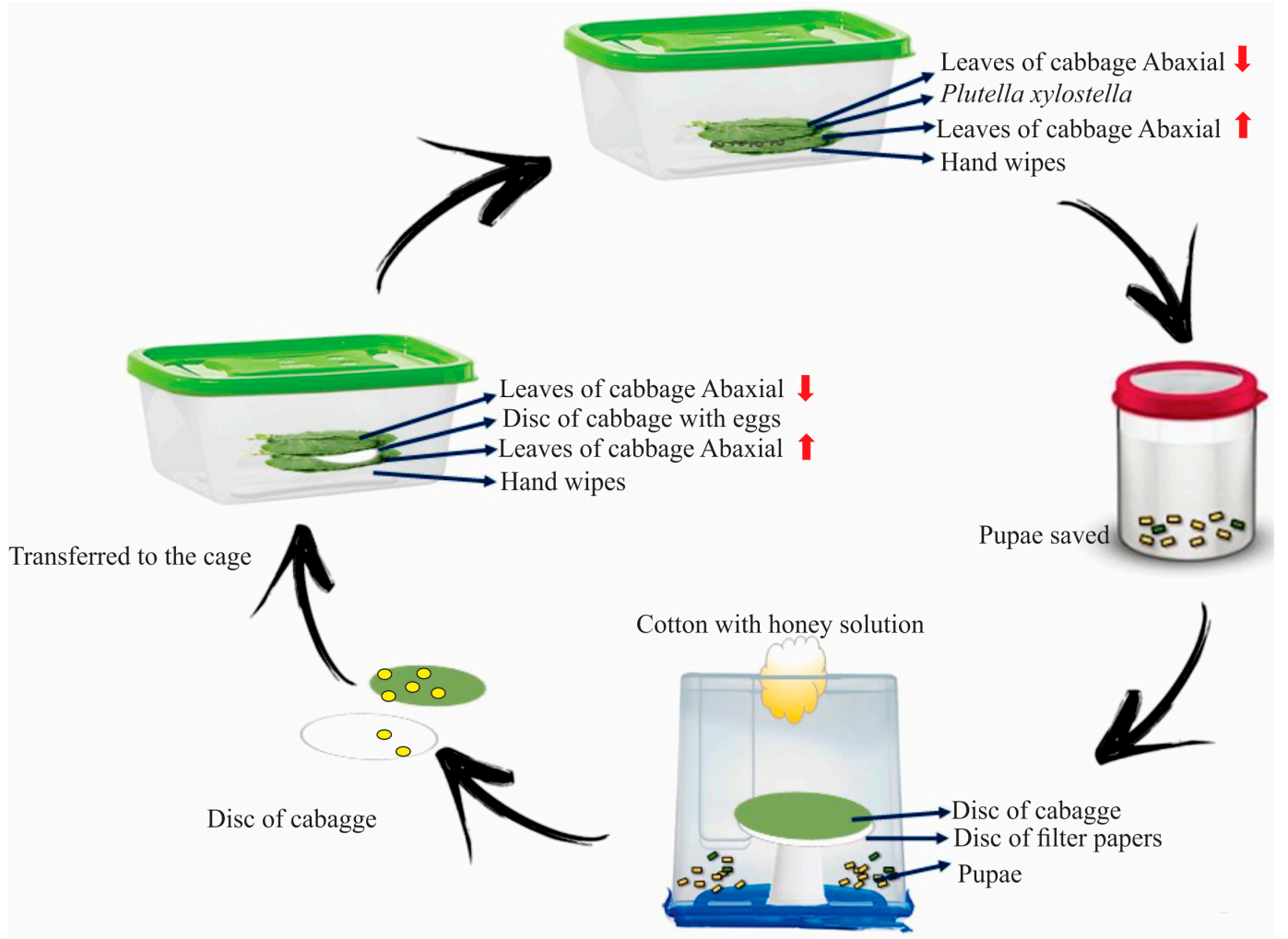

Figure 1. A schematic representation of the methodology used for rearing Plutella xylostella, by Matias da Silva et al. [34]. 
Expanded leaves of Alibertia edulis, Alibertia intermedia, and Alibertia sessilis were collected from Coqueiro farm in the municipality of Dourados, MS ( $22^{\circ} 12^{\prime} \mathrm{S} 54^{\circ} 54^{\prime} \mathrm{W} ; 452 \mathrm{~m}$ altitude) from 7 a.m. to 9 a.m. Authorization for collection of botanical material was granted by the Brazilian National Research Council (CNPq)/Council of Genetic Heritage Management (CGEN/MMA, number 010220/2015-1).

The plant species were identified by a specialist in the laboratory of Applied Botany, and exsiccated samples were deposited at the Herbarium of the Federal University of Grande Dourados, Mato Grosso do Sul, Brazil, with the following registration numbers: Alibertia edulis: 5409; Alibertia intermedia: 5408; and Alibertia sessilis: 5410.

\subsection{Preparation of Aqueous Extracts}

The leaves of A. edulis, A. intermedia, and A. sessilis were dried in a forced circulating air oven for three days at a maximum temperature of $40^{\circ} \mathrm{C}\left( \pm 1^{\circ} \mathrm{C}\right)$. Thereafter, they were ground in a mill to obtain a fine powder.

Aqueous extracts of A. edulis, A. intermedia, and A. sessilis were prepared by maceration. In total, $10 \mathrm{~g}$ of the aforementioned powder was manually shaken with $100 \mathrm{~mL}$ of distilled water. The extracts were cooled at $10{ }^{\circ} \mathrm{C}$ for $24 \mathrm{~h}$ and, thereafter, filtered through voile fabric, yielding extracts with a $10 \%$ $(w / v)$ concentration.

\subsection{Bioactivity of A. edulis, A. intermedia, and A. sessilis Aqueous Extracts against P. xylostella}

To assess the bioactivity of the extracts of A. edulis, A. intermedia, and A. sessilis, cabbage leaf discs (B. oleracea var. acephala) of $8 \mathrm{~cm}$ in diameter were immersed in the aqueous extracts $(10 \mathrm{~g} / \mathrm{mL})$ for $1 \mathrm{~min}$. A control was also prepared by immersing identical discs in distilled water. After immersion, the discs were placed on filter paper at room temperature to remove excess moisture, and subsequently transferred to Petri dishes. A single newly-hatched (0-24 h) P. xylostella larva was placed in each Petri dish, as determined by the cabbage disc area. The tests were conducted at a temperature of $25 \pm 2{ }^{\circ} \mathrm{C}$, a $\mathrm{RH}$ of $55 \% \pm 5 \%$, and a photoperiod of $12 \mathrm{~h}$.

To determine larval stage duration, the larvae were monitored continuously until they reached the pupal stage. Since the larvae remained in the parenchyma of the first leaf, the first mortality assessment was performed $48 \mathrm{~h}$ after confinement. This assessment consisted of counting the number of dead individuals and replacing cabbage leaf discs. Subsequent evaluations were conducted daily and leaf discs were replaced every $24 \mathrm{~h}$ with treated discs (immersed in an aqueous extract $(10 \mathrm{~g} / \mathrm{mL}$ ) for $1 \mathrm{~min}$ ). Pupal survival was determined by isolating individual pupae in 24 or 96 well ELISA plates (Biomerica, Irvine, CA, USA). The pupae were weighed $24 \mathrm{~h}$ thereafter and observed.

To evaluate the reproductive stage, eight pairs $(n=16)$ from each treatment, with the exception of A. sessilis (two pairs, $n=4$ ), were maintained separately in plastic cages containing cabbage leaf discs as oviposition substrates. The fecundity was evaluated daily and larval hatching was observed.

We evaluated the following biological parameters: duration and survival of larval and pupal stages, pupal weight (Bel Mark Analytical Balance, BEL Engineering, Monza, MB, Italy), female and male longevity, sex ratio (female/(female + male), fecundity (total number of eggs deposited throughout life), oviposition (oviposition period (days) = the period between the first and last laying), incubation period (incubation period (days) = the period between egg laying and hatching of larvae), and egg survival (Figure 2).

In addition, individuals with deformities were assessed with respect to the shape and color of the pupae and adult wing shape.

The experimental design was completely randomized, with each treatment consisting of 10 replications of five sub-samples for a total of 50 larvae per treatment. To evaluate the longevity of adult males and females, fecundity, and egg survival of $P$. xylostella, the data were analyzed in a completely randomized design with different repetition number. Data were processed through arcsine transformation, with initial values for larval and pupal survival first converted by $\sqrt{ } x / 100$ 
and initial values for larval and pupal duration, male and female longevity, and fecundity converted by $\sqrt{ } x+0.5$. The results were submitted to analysis of variance and means were compared with the Tukey test.

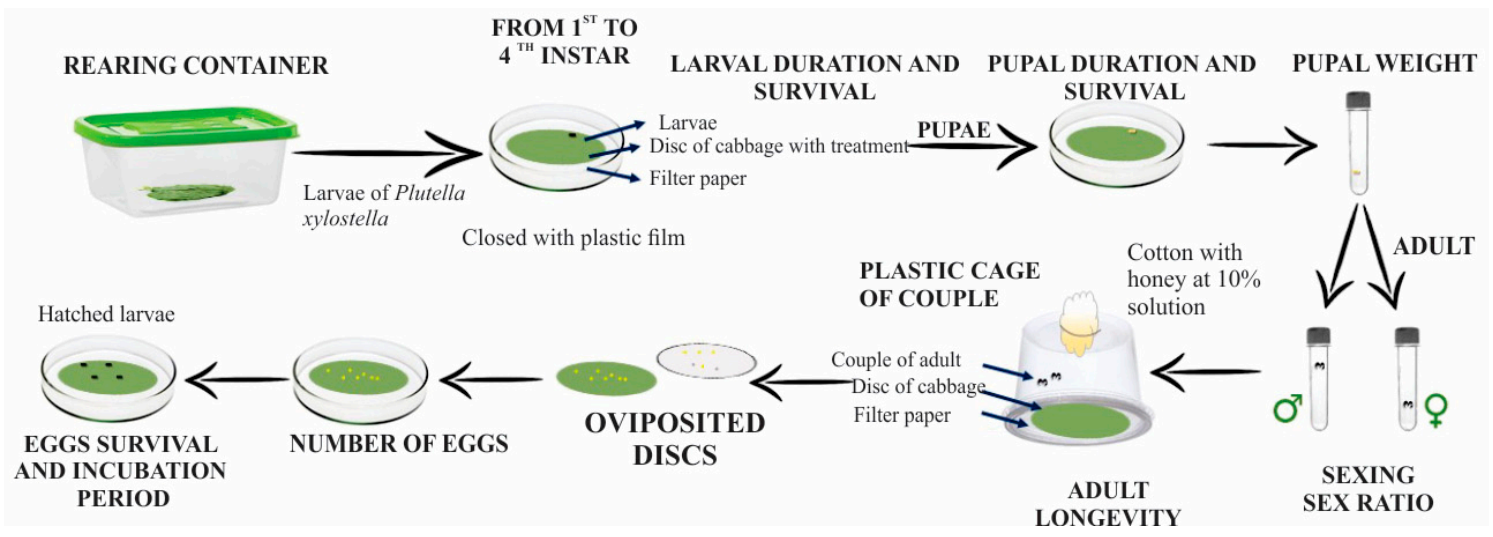

Figure 2. A schematic representation of the methodology used for evaluation of biological parameters, by Matias da Silva et al. [34].

\subsection{Identification of Compounds by High-Performance Liquid Chromatography (HPLC)}

The standards and aqueous extracts were analyzed using a Shimadzu LC-6 system, equipped with a diode array detector reading at 200-600 nm, a binary pump, Lab Solution software, a reverse phase C-18 column $(25 \mathrm{~cm} \times 4.6 \mathrm{~mm} \times 5 \mu \mathrm{m})$, and a pre-column $(2.5 \mathrm{~cm} \times 3 \mathrm{~mm})$ of the same phase. The mobile phase consisted of $6 \%$ acetic acid in water with $2 \mathrm{mM}$ sodium acetate solution (eluent $\mathrm{A}$ ) and acetonitrile (eluent $\mathrm{B}$ ). The analyses were performed using the following gradient elution system: $0 \mathrm{~min}, 5 \% \mathrm{~B}$; $30 \mathrm{~min}, 15 \% \mathrm{~B} ; 35 \mathrm{~min}, 30 \% \mathrm{~B} ; 40 \mathrm{~min}, 50 \% \mathrm{~B} ; 45 \mathrm{~min}, 100 \% \mathrm{~B}$. The analysis time was $45 \mathrm{~min}$, the flow stream of the pump was $1 \mathrm{~mL} / \mathrm{min}$, and the injected volume was $10 \mu \mathrm{L}$ of extract at a concentration of $100 \mu \mathrm{g} / \mathrm{mL}$.

The compounds in the samples were identified and quantified by comparing the retention times of the samples with the retention times of pure commercial standards (Sigma-Aldrich, Saint Louis, MO, USA). Standards of caffeic acid, ferrulic acid, $p$-coumaric acid, benzoic acid, cinnamic acid, rutin, quercetin, luteolin, and apigenin (Sigma, $\geq 97 \%$ purity) were prepared at an initial concentration of $100 \mu \mathrm{g} / \mathrm{mL}$. The concentrations of compounds were determined by external calibration after preparing appropriate dilutions in the range $0.01-10 \mu \mathrm{g} / \mathrm{mL}$.

\section{Results}

\subsection{Effect of the Extracts on the Development and Reproduction of P. xylostella}

The larvae that were fed on leaves treated with $A$. edulis extract exhibited a reduction in larval period of up to 1.14 days compared with the control $(\mathrm{F}=122.24 ; \mathrm{DF}=3 ; p \leq 0.001)$. The extracts of $A$. intermedia and $A$. sessilis caused higher mortality, but prolonged the duration of the larval phase by 3.11 and 2.35 days, respectively, compared with the control (Table 1). The action of $A$. intermedia and A. sessilis prevented several larvae from reaching the pupal stage.

Reductions of $43.59 \%(n=50)$ and $50.2 \%(n=50)$ were observed in the larval survival of $A$. intermedia and $A$. sessilis treated larvae, respectively, when compared with the control. Neither the A. edulis extract nor the control promoted significant mortality, with larval survivals greater than $92 \%$ being recorded $(n=50)$ (Table 1$)$.

For A. edulis extract treatments and control, the pupal duration was 5.67 and 6.08 days, respectively, showing no significant difference. However, $A$. intermedia and $A$. sessilis extracts caused a significant reduction in comparison with the control and $A$. edulis, with values of 3.45 and 2.36 days $(F=13.44$; 
$p \leq 0.00003)$, respectively. For pupal survival, there was a higher mortality in treatments with the extracts of $A$. sessilis, with an adult emergence of $37.19 \%(\mathrm{~F}=7.93 ; p \leq 0.00055)$ (Table 1$)$. Although aqueous extracts of $A$. intermedia and $A$. sessilis extended the larval duration compared with the control, this was not reflected by any increase in pupal weight. Specifically, A. sessilis ( $3.46 \mathrm{mg})$ and A. intermedia $(3.88 \mathrm{mg}$ ) weights were considerably lower than that of the control $(5.26 \mathrm{mg})$ (Table 1). The extracts that caused a reduction in pupal weight exerted higher mortalities in this stage. There was no significant difference in sex ratio between treatments $(\mathrm{F}=0.7659 ; p \leq 0.52338)$.

Table 1. Duration (days) and survival (\%) of larval and pupal stages and pupal weight (mg) of Plutella xylostella L. treated with Alibertia edulis, Alibertia intermedia, and Alibertia sessilis aqueous extracts.

\begin{tabular}{|c|c|c|c|c|c|}
\hline Treatment & $\begin{array}{l}\text { Larval Duration } \\
\text { (Days) }\end{array}$ & $\begin{array}{c}\text { Larval } \\
\text { Survival (\%) }\end{array}$ & $\begin{array}{c}\text { Pupal Duration } \\
\text { (Days) }\end{array}$ & $\begin{array}{c}\text { Pupal Survival } \\
(\%)\end{array}$ & $\begin{array}{l}\text { Pupal Weight } \\
\text { (mg) }\end{array}$ \\
\hline Control & $\begin{array}{c}5.86 \pm 0.21 \mathrm{~b} * \\
n=50\end{array}$ & $\begin{array}{c}96.67 \pm 4.3 \mathrm{a} \\
n=50\end{array}$ & $\begin{array}{c}6.08 \pm 0.17 \mathrm{a} \\
n=46\end{array}$ & $\begin{aligned} 98.49 & \pm 4.44 \mathrm{a} \\
n & =46\end{aligned}$ & $\begin{array}{c}5.26 \pm 0.3 \mathrm{a} \\
n=46\end{array}$ \\
\hline A. edulis & $\begin{array}{c}4.72 \pm 0.15 c \\
n=50\end{array}$ & $\begin{array}{c}92.46 \pm 3.3 \mathrm{a} \\
n=50\end{array}$ & $\begin{array}{c}5.67 \pm 0.12 \mathrm{a} \\
n=44\end{array}$ & $\begin{aligned} 97.73 & \pm 3.59 \mathrm{a} \\
n & =44\end{aligned}$ & $\begin{array}{c}4.61 \pm 0.4 \mathrm{ab} \\
n=44\end{array}$ \\
\hline A. intermedia & $\begin{array}{c}8.97 \pm 0.19 \mathrm{a} \\
n=50\end{array}$ & $\begin{array}{c}56.41 \pm 6.5 \mathrm{~b} \\
n=50\end{array}$ & $\begin{array}{c}3.45 \pm 0.12 \mathrm{~b} \\
n=28\end{array}$ & $\begin{array}{c}96.34 \pm 5.83 \mathrm{a} \\
n=28\end{array}$ & $\begin{array}{c}3.88 \pm 0.2 \mathrm{bc} \\
n=28\end{array}$ \\
\hline A. sessilis & $\begin{array}{c}8.21 \pm 0.13 \mathrm{a} \\
n=50\end{array}$ & $\begin{array}{c}49.80 \pm 4.5 \mathrm{~b} \\
n=50\end{array}$ & $\begin{array}{c}2.36 \pm 0.64 \mathrm{~b} \\
n=25\end{array}$ & $\begin{array}{c}37.19 \pm 11.7 \mathrm{~b} \\
n=11\end{array}$ & $\begin{array}{c}3.46 \pm 0.2 \mathrm{c} \\
n=11\end{array}$ \\
\hline CV (\%) & 3.9 & 21.64 & 16.4 & 30.55 & 20.6 \\
\hline
\end{tabular}

* Means followed by different letters in the same column differ at $5 \%$ significance level when compared using the Tukey test; $n=$ number of individuals.

In the adult stage, there was no significant difference between treatments for female longevity $(\mathrm{F}=1.405 ; p=0.267)$; however, males exposed to A. edulis showed an increase in longevity (19.37 days) $(\mathrm{F}=6.889 ; p=0.002)$ (Table 2).

Table 2. Longevity of adult males and females, fecundity and egg survival (\%) of Plutella xylostella L. treated with of Alibertia edulis, Alibertia intermedia, and Alibertia sessilis aqueous extracts.

\begin{tabular}{ccccc}
\hline Treatment & $\begin{array}{c}\text { Longevity of } \\
\text { Males (Days) }\end{array}$ & $\begin{array}{c}\text { Longevity of } \\
\text { Females (Days) }\end{array}$ & Fecundity & Survival of Eggs (\%) \\
\hline Control & $\begin{array}{c}13.26 \pm 1.41 \mathrm{~b} * \\
n=8\end{array}$ & $\begin{array}{c}12.43 \pm 1.19 \mathrm{a} \\
n=8\end{array}$ & $198.08 \pm 9.44 \mathrm{a}$ & $91.75 \pm 1.14 \mathrm{a}$ \\
\hline A. edulis & $\begin{array}{c}19.37 \pm 1.14 \mathrm{a} \\
n=8\end{array}$ & $\begin{array}{c}12.81 \pm 0.66 \mathrm{a} \\
n=8\end{array}$ & $187.57 \pm 17.53 \mathrm{a}$ & $71.04 \pm 4.07 \mathrm{ab}$ \\
\hline A. intermedia & $\begin{array}{c}14.66 \pm 0.86 \mathrm{~b} \\
n=8\end{array}$ & $\begin{array}{c}12.39 \pm 0.90 \mathrm{a} \\
n=8\end{array}$ & $86.69 \pm 18.46 \mathrm{~b}$ & $66.24 \pm 9.53 \mathrm{~b}$ \\
\hline A. sessilis & $\begin{array}{c}10.49 \pm 0.50 \mathrm{~b} \\
n=2\end{array}$ & $\begin{array}{c}8.97 \pm 1.0 \mathrm{a} \\
n=2\end{array}$ & $95.38 \pm 6.5 \mathrm{ab}$ & $77.41 \pm 3.95 \mathrm{ab}$ \\
\hline CV (\%) & 10.15 & 10.1 & 20.36 & 21.97 \\
\hline
\end{tabular}

* Means followed by different letters in the same column differ at 5\% significance level when compared using the Tukey test; $n=$ number of individuals.

The lowest fecundity was observed in the treatment with $A$. intermedia (86.69) and A. sessilis (95.38) $(\mathrm{F}=6.7241 ; p \leq 0.00248)$. Treatment with all the extracts resulted in a reduction in the number of surviving eggs, with $A$. intermedia (66.24) treatment resulting in the lowest number of hatched larvae (Table 2).

The incubation period for all treatments averaged 3.25 days, with no significant difference among treatments. The oviposition period averaged three days for all treatments.

Morphological changes were observed in P. xylostella when treated with aqueous extracts of A. sessilis and A. intermedia (Figure 3A-F). The A. sessilis-treated adults had atrophied wings (Figure 3A), 
whereas pupae had flaccid bodies (Figure 3F) and larvae had a dark color and appeared to be rotting (Figure 3D). Furthermore, individuals exposed to A. intermedia died at the pupal stage (Figure 3B or Figure 3E), whereas larvae exhibited a similar dark color (Figure 3C).
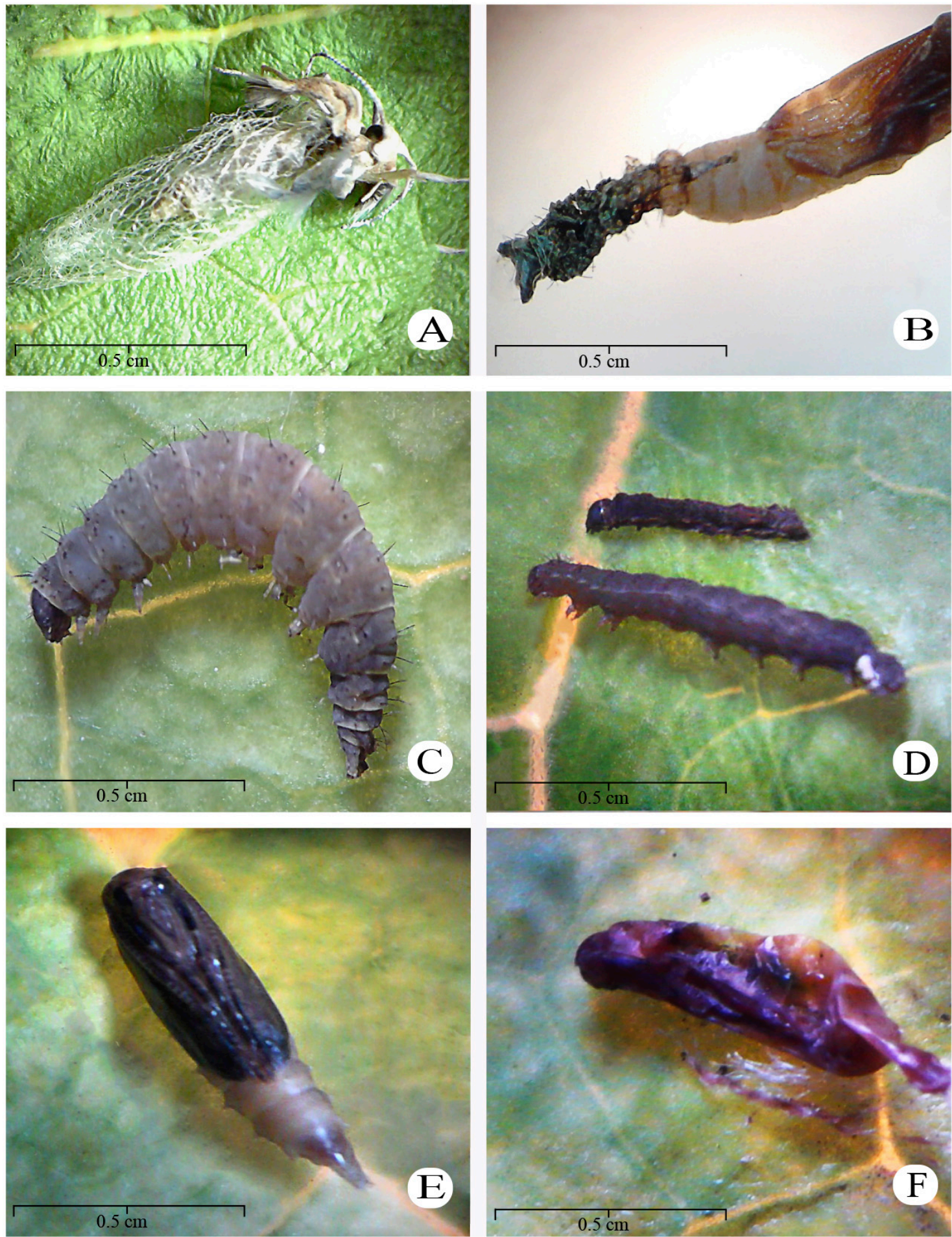

Figure 3. Deformities were observed in adults (A), pupae (B,E,F), and larvae (C,D) of Plutella xylostella. $(\mathbf{A}, \mathbf{D}, \mathbf{F})$ show the effects of Alibertia sessilis; $(\mathbf{B}, \mathbf{C}, \mathbf{E})$ show the effects of Alibertia intermedia. 


\subsection{Compounds in Aqueous Extracts}

Caffeic acid was the only analyzed compound that was present in all the samples examined, whereas $p$-coumaric acid was present only in $A$. sessilis. In addition, rutin, quercetin, and luteolin were present in both $A$. intermedia and $A$. sessilis. $A$. sessilis was the only species that contained all the compounds tested (Figure 4). Table 3 shows the contents of compounds in the samples.
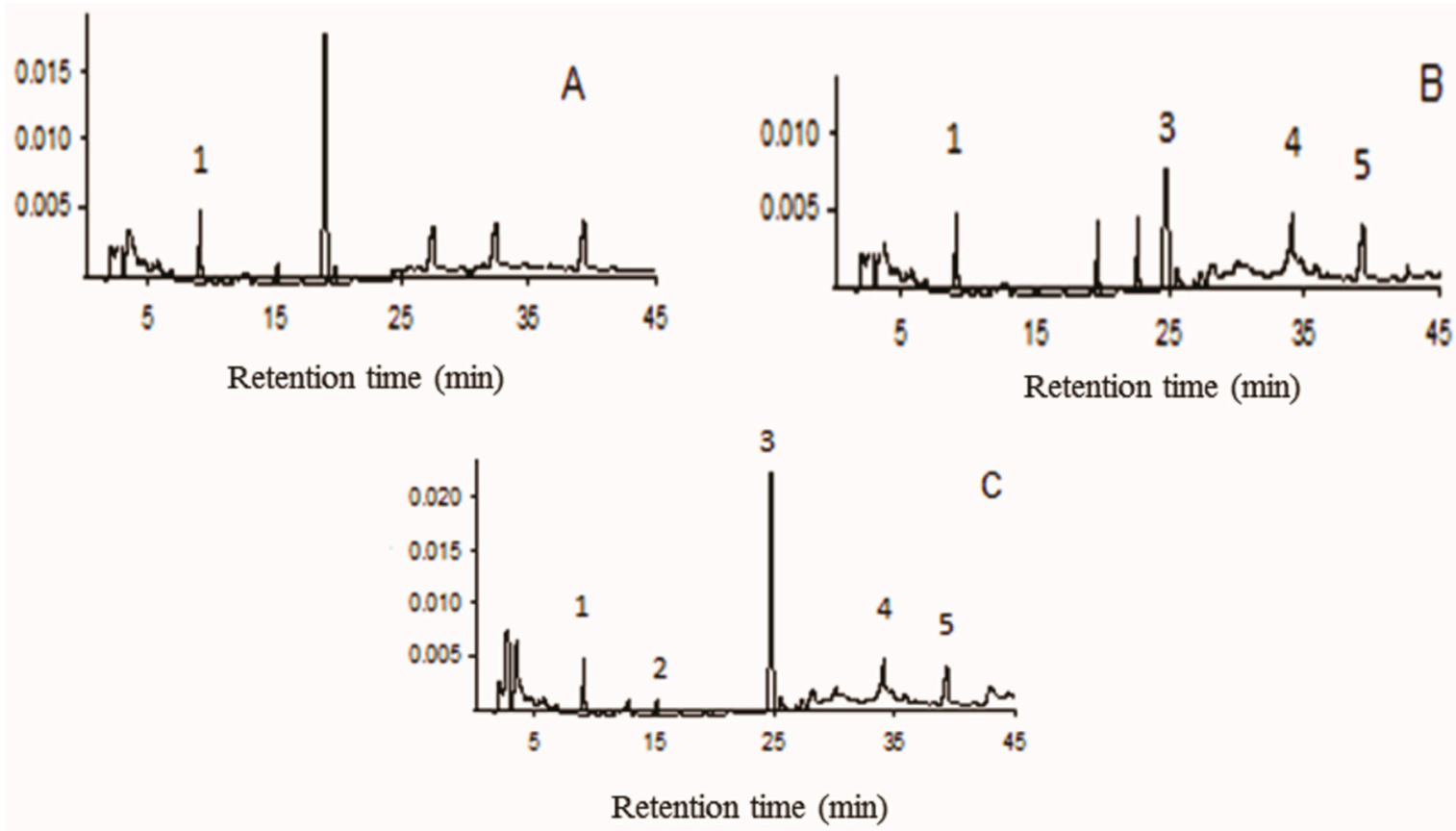

Figure 4. Chromatograms obtained from aqueous extract samples of (A) Alibertia edulis, (B) Alibertia intermedia, and (C) Alibertia sessilis leaves.

Table 3. Compounds identified and quantified by HPLC analysis.

\begin{tabular}{cccccc}
\hline Peaks & Compound & $\begin{array}{c}\text { Retention } \\
\text { Time }(\mathbf{m i n})\end{array}$ & $\begin{array}{c}\text { Concentration } \\
(\mathbf{m g} / \mathbf{g} \pm \mathbf{S D}) \\
\mathbf{A}\end{array}$ & $\begin{array}{c}\text { Concentration } \\
(\mathbf{m g} / \mathbf{g} \pm \mathbf{S D}) \\
\mathbf{B}\end{array}$ & $\begin{array}{c}\text { Concentration } \\
(\mathbf{m g} / \mathbf{g} \pm \mathbf{S D}) \\
\mathbf{C}\end{array}$ \\
\hline 1 & Caffeic acid & 10.1 & $51.8 \pm 0.1$ & $48.9 \pm 0.3$ & $47.8 \pm 0.2$ \\
\hline 2 & $\begin{array}{c}p \text {-Coumaric } \\
\text { acid }\end{array}$ & 15.2 & - & - & $10.7 \pm 0.4$ \\
\hline 3 & Rutin & 24.7 & - & $88.9 \pm 0.3$ & $178.9 \pm 0.6$ \\
\hline 4 & Quercetin & 34.5 & - & $25.7 \pm 0.1$ & $23.9 \pm 0.1$ \\
\hline 5 & Luteolin & 39.7 & - & $32.5 \pm 0.2$ & $33.1 \pm 0.1$ \\
\hline
\end{tabular}

$\mathrm{SD}=$ Standard deviation; "-" = absent values.

\section{Discussion}

The Rubiaceae species used in this study showed reasonable results regarding their ability to control P. xylostella populations. Many previous studies on insects have indicated the antibiosis effects of the substances identified in the extracts of the present study. These substances inhibit food consumption and the morphological and physiological transformations of the pupal stage, which require intense biochemical activity [35-39]. In this study, substances acted during insect metamorphosis - some individuals died between the larval and pupal stages, whereas others emerged as adults with malformed wings or other body parts. 
Caffeic acid was found in all three plant species analyzed. Studies have shown the deleterious effect of caffeic acid on larvae of Helicoverpa zea (Boddie, 1850) (Lepidoptera: Noctuidae). This compound has potential action in lipid peroxidation and the oxidation of proteins and free iron [38], which could explain the different effects on larval growth and development. Since this was the only compound present in all the extracts analyzed, we believe that it might induce the deformations observed by acting synergistically with other compounds. In addition, other studies have shown that caffeic acid is one of the most efficient feed deterrent compounds against insects [40]. In the great majority of insects, the midgut is the main site of food digestion and assimilation. The feeding habits in Lepidoptera exhibit a different pattern of alkalinity in the midgut, which is related with the physicochemical characteristics of the plant consumed [41]. Changes in the pattern of alkalinity can probably affect the biological and metabolic activities of these insects. Taking this into account, plants containing phenolic compounds, such as caffeic acid, might cause numerous effects on these herbivores, including toxicity [42].

$p$-Coumaric acid, which was observed only in A. sessilis, is described as being responsible for the resistance of corn plants against Sesamia nonagrioides (Lepidoptera: Noctuidae) [43] and Prostephunus truncatus (Horn) (Coleoptera: Bostrichidae) [44]. However, in this study, $p$-coumaric was present only in A. sessilis, where it might act as a potential enhancer of synergistic interactions [43], reducing the percentage of larval and pupal survival and pupal weight, and decreasing the longevity of P. xylostella females below that observed in the control and other treatments.

In this study, we found that rutin was present in A. intermedia and A. sessilis extracts, and that the concentration is twice as high in the latter. We observed an increased duration of the larval stage, and a reduced pupal stage, pupal weight, and fecundity in P. xylostella treated with extracts of A. intermedia and A. sessilis. Rutin contributes to plant protection due to its anti-feeding action against Lepidoptera [45]. The actions caused by this flavonoid might extend the larval cycle and cause mortality when added to the diet [46,47], reduce growth and larval and pupal weight [48], decrease pupal survival [49], block feeding, and inhibit digestion and the formation of free radicals [42]. In Lepidoptera, rutin negatively affects the growth of Anticarsia gemmatalis Hübner (Lepidoptera: Noctuidae), which is due to pre-ingestion effects, as indicated by reduced consumption, and post-ingestion effects, as indicated by low conversion rates of food ingested into biomass and food assimilation [47]. Rutin also negatively affects the biology of Spodoptera frugiperda (Smith, 1797) (Lepidoptera: Noctuidae) by increasing the larval period, and reducing larval and pupal weight and pupal survival [49]. We highlight, however, that further studies are needed to understand the synergic interaction between compounds [43] and the isolates of each compound found in the extracts.

The quercetin present in $A$. intermedia and $A$. sessilis influences the biology of insects. While assessing the biology of the soy-caterpillar, A. gemmatalis, we observed that quercetin and rutin increased the length of the total life cycle (third instar until the adult stage), and enhanced the mortality rate of caterpillars [50]. The authors observed that by administering quercetin, there was a reduction in the mortality rate and pupal weight; however, the phase duration was not changed. The results showed that the effects of this flavonoid on insects appear from the third or fourth instar, but are more intense in the fifth and sixth instars.

Luteolin is a flavonoid that impedes insect oviposition on leaves [51,52], and this characteristic corroborates the results obtained in the present study with respect $A$. intermedia and $A$. sessilis treatments. In Acyrthosiphon pisum Harris (Homoptera: Aphididae), we observed changes in fecundity with different doses of luteolin [53]. Thus, it is possible that this flavonoid is directly related to changes in insect fecundity, reinforcing the hypothesis of a correlation between this compound and fecundity.

We highlight, however, that the roles of these compounds in plant-insect interactions are very variable. Nevertheless, many flavonoids, depending on the dose, do reduce food intake [54-59].

We believe that the flavonoids rutin, quercetin, and luteolin present in A. intermedia and A. sessilis are probably responsible for the changes in P. xylostella observed in the present study. 
Given these results and the consulted literature, we believe that the observed insect-plant inter-relationships would ensure crop protection. Nevertheless, the responses of insects to phenolic compounds are variable and, thus, warrant further in-depth studies on the relevant mechanisms of action, since many aspects remain unknown.

\section{Conclusions}

The results of this study have contributed to enhancing our understanding of the insecticidal activity of species of Alibertia against P. xylostella. The species, particularly A. intermedia and A. sessilis, should, accordingly, be the focus of further in-depth studies for more thorough assessments. However, given that these results were obtained under laboratory conditions, semi-field and field studies should also be conducted, particularly using the substances identified in this study.

Acknowledgments: The authors would like to thank the Foundation to Support to Development of Education, Science and Technology of Mato Grosso do Sul State (FUNDECT)-Process: 59/300.029/2015, Brazilian National Research Council (CNPq)-Process: 304302/2015-5 Coordination of Improvement of Higher Level (CAPES) and Dra. Zefa Valdivina Pereira the identification of species. The funders had no role in study design, data collection and analysis, decision to publish, or preparation of the manuscript. The FFP, SPQS, and CALC are CNPq research productivity fellows. We thank Samuel Boff the comments, reading and suggestions to the manuscript. We wish to thank São Paulo Research Foundation (FAPESP) for financial support (grant 2008/00522-9).

Author Contributions: Conceived and designed the experiments: Lucas L. S. Peres and Rosilda M. Mussury. Performed the experiments: Lucas L. S. Peres, Ana I. Sobreiro, Irys F. S. Couto, and Rosicléia M. Silva. Analyzed the data: Lucas L. S. Peres, Rosilda M. Mussury, Fabricio F. Pereira, Silvia C. H. Vieira, and Claudia A. L. Cardoso. Contributed materials/analysis tools: Rosilda M. Mussury. Wrote the paper: Lucas L. S. Peres, Ana I. Sobreiro, Rosilda M. Mussury, Fabricio F. Pereira, Silvia C. Heredia-Vieira, Claudia A. L. Cardoso, Munir Mauad, Silvana P. Q. Scalon, and Sandra S. Verza.

Conflicts of Interest: The authors declare no conflict of interest.

\section{References}

1. Furlong, M.J.; Wright, D.J.; Dosdall, L.M. Diamondback moth ecology and management: Problems, progress, and prospects. Annu. Rev. Entomol. 2013, 58, 517-541. [CrossRef] [PubMed]

2. Zalucki, M.P.; Shabbir, A.; Silva, R.; Adamson, D.; Shu-Sheng, L.; Furlong, M.J. Estimating the economic cost of one of the world's major insect pests, Plutella xylostella: Just how long is a piece of string? J. Econ. Entomol. 2012, 105, 1115-1129. [CrossRef] [PubMed]

3. Hamilton, A.J.; Endersby, N.M.; Ridland, P.M.; Zhang, J.; Neal, M. Effects of cultivar on oviposition preference, larval feeding and development time of diamondback moth, Plutella xylostella (L.) (Lepidoptera: Plutellidae), on some Brassica oleracea vegetables in Victoria. Aust. J. Entomol. 2005, 44, 284-287. [CrossRef]

4. Talekar, N.S.; Shelton, A.M. Biology, ecology, and management of the diamondback moth. Annu. Rev. Entomol. 1993, 38, 275-301. [CrossRef]

5. Pérez, C.J.; Alvarado, P.; Narváez, C.; Hernández, L.; Vanegas, H.; Hruska, A.; Shelton, A.M. Assessment of insecticide resistance in five insect pests attacking field and vegetable crops in Nicaragua. J. Econ. Entomol. 2000, 93, 1779-1787. [CrossRef] [PubMed]

6. Castelo Branco, M.; Gatehouse, A.G. Insecticide resistance in Plutella xylostella (L.) (Lepidoptera: Yponomeutidae) in the Federal District, Brazil. An. Soc. Entomol. Bras. 1997, 26, 75-79. [CrossRef]

7. Santos, V.C.; Siqueira, H.A.A.; Silva, J.E.; Farias, M.J.D.C. Insecticide resistance in populations of the diamondback moth, Plutella xylostella (L.) (Lepidoptera: Plutellidae), from the state of Pernambuco, Brazil. Neotrop. Entomol. 2011, 40, 264-270. [CrossRef] [PubMed]

8. Amoabeng, B.W.; Gurr, G.M.; Gitau, C.W.; Nicol, H.I.; Munyakazi, L.; Stevenson, P.C. Tri-Trophic insecticidal effects of African plants against cabbage pests. PLoS ONE 2013. [CrossRef]

9. Wei, X.; Zhang, X.; Shen, D.; Wang, H.; Wu, Q.; Lu, P.; Qiu, Y.; Song, J.; Zhang, Y.; Li, X. Transcriptome analysis of Barbarea vulgaris infested with Diamondback Moth (Plutella xylostella) Larvae. PLoS ONE 2013. [CrossRef]

10. Dong, X.; Zhai, Y.; Hu, M.; Zhong, G.; Huang, W.; Zheng, Z.; Han, P. Proteomic and properties analysis of botanical insecticide rhodojaponin III-Induced response of the Diamondback Moth, Plutella xyllostella (L.). PLoS ONE 2013. [CrossRef] [PubMed] 
11. Ouyang, L.; Xu, X.; Freed, S.; Gao, Y.; Yu, J.; Wang, S.; Ju, W.; Zhang, Y.; Jin, F. Cecropins from Plutella xylostella and their interaction with Metarhizium anisopliae. PLoS ONE 2015. [CrossRef] [PubMed]

12. Amoabeng, B.W.; Gurr, G.M.; Gitau, C.W.; Stevenson, P.C. Cost: Benefit analysis of botanical insecticide use in cabbage: Implications for smallholder farmers in developing countries. Crop Prot. 2014, 57, 71-76. [CrossRef]

13. Kudom, A.A.; Mensah, B.A.; Botchey, M.A. Aqueous neem extract versus neem powder on Culex quinquefasciatus: Implications for control in anthropogenic habitats. J. Insect Sci. 2011, 11, 142. [CrossRef] [PubMed]

14. Ladhari, A.; Laarif, A.; Omezzine, F.; Haouala, R. Effect of the extracts of the spiderflower, Cleome arabica, on feeding and survival of larvae of the cotton leafworm, Spodoptera littoralis. J. Insect Sci. 2013, 13, 1-14. [CrossRef] [PubMed]

15. Schmutterer, H. Potential of azadirachtin-containing pesticides for integrated pest control in developing and industrialized countries. J. Insect Physiol. 1988, 34, 713-719. [CrossRef]

16. Mordue, A.J.; Blackwell, A. Azadirachtin: An update. J. Insect Physiol. 1993, 39, 903-924. [CrossRef]

17. Deletre, E.; Martin, T.; Campagne, P.; Bourguet, D.; Cadin, A.; Menut, C.; Bonafos, R.; Chandre, F. Repellent, irritant and toxic effects of 20 plant extracts on adults of the malaria vector Anopheles gambiae Mosquito. PLoS ONE 2013. [CrossRef] [PubMed]

18. Krinski, D.; Massaroli, A.; Machado, M. Potencial inseticida de plantas da família Annonaceae. Rev. Bras. Frutic. 2014, 36, 225-242. (In Portuguese) [CrossRef]

19. Couto, I.F.S.; Fuchs, M.L.; Pereira, F.F.; Mauad, M.; Scalon, S.P.Q.; Dresch, D.M.; Mussury, R.M. Feeding preference of Plutella xylostella for leaves treated with plant extracts. An. Acad. Bras. Cienc. 2016, 88, 1781-1789. [CrossRef] [PubMed]

20. Luciano, J.H.S.; Lima, M.A.S.; Souza, E.B.; Silveira, E.R. Chemical constituents of Alibertia myrciifolia Spruce ex K. Schum. Biochem. Syst. Ecol. 2004, 32, 1227-1229. [CrossRef]

21. Schripsema, J.; Dagnina, D.; Grosman, G. Alcalóides indólicos. In Farmacognosia da Planta ao Medicamento, 5th ed.; Simões, C.M.O., Schenkel, E.P., Gosmann, G., Mello, J.C.P., Mentz, L.A., Petrovick, P.R., Eds.; Editora da UFRGS/UFSC: Porto Alegre/Florianópolis, Brasil, 2004; pp. 819-846. (In Portuguese)

22. Keutgen, A.J.; Pawelzik, E. Modifications of strawberry fruit antioxidant pools and fruit quality under $\mathrm{NaCl}$ stress. J. Agric. Food Chem. 2007, 55, 4066-4072. [CrossRef] [PubMed]

23. Bolzani, V.S.; Trevisan, L.M.V.; Young, M.C.M. Caffeic acid esters and triterpenes of Alibertia macrophylla. Phytochemistry 1991, 30, 2089-2091. [CrossRef]

24. Olea, R.S.G.; Roque, N.F.; Bolzani, V.S. Acylated flavonol glycosides and terpenoids from the leaves of Alibertia sessilis. J. Braz. Chem. Soc. 1997, 8, 257-259. [CrossRef]

25. Moura, V.M.; Santos, D.P.; Santin, S.M.O.; Carvalho, J.E.; Foglio, M.A. Constituintes químicos de Galianthe brasiliensis (Rubiaceae). Quim. Nova 2006, 29, 452-455. (In Portuguese) [CrossRef]

26. Lebrini, M.; Robert, F.; Roos, C. Alkaloids extract from Palicourea guianensis plant as corrosion inhibitor for C38 steel in $1 \mathrm{M}$ hydrochloric acid medium. Int. J. Electrochem. Sci. 2011, 6, 847-859.

27. Ling, S.K.; Komorita, A.; Tanaka, T.; Fujioka, T.; Mihashi, K.; Kouno, I. Iridoids and anthraquinones from the Malaysian medicinal plant, Saprosma scortechinii (Rubiaceae). Chem. Pharm. Bull. 2002, 50, 1035-1040. [CrossRef] [PubMed]

28. Silva, V.C.; Silva, G.H.; Bolzani, V.S.; Lopes, M.N. Isolation of lignans glycosides from Alibertia sessilis (Vell.) K. Schum. (Rubiaceae) by preparative high-performance liquid chromatography. Eclet. Quim. 2006, 31, 55-58. [CrossRef]

29. Silva, W.C.; Pinheiro, C.C.S.; Rodrigues, J.M.G.; Souza, H.E.M.; Ribeiro, J.D. Avaliação do efeito tóxico de extratos de Palicourea marcgravii St. Hil. (Rubiaceae) sobre Aetalion sp. (Hemiptera: Aetalionidae) em laboratório. R. Bras. Bioci. 2009, 7, 129-133. (In Portuguese)

30. Gonzaga, A.D.; Ribeiro, J.D.; Vieira, M.F.; Alécio, M.R. Toxidez de três concentrações de erva-de-rato (Palicourea marcgravii A. St.-Hill) e Manipueira (Manihot esculenta Crantz) em pulgão verde dos Citros (Aphis spiraecola Patch) em casa de vegetação. R. Bras. Bioc. 2007, 5, 55-56. (In Portuguese)

31. Gao, G.; Lu, Z.; Tao, S.; Zhang, S.; Wang, F. Triterpenoid saponins with antifeedant activities from stem bark of Catunaregam spinosa (Rubiaceae) against Plutella xylostella (Plutellidae). Carbohydr. Res. 2011, 346, 2200-2205. [CrossRef] [PubMed] 
32. Jacobson, M. Botanical pesticides: Past, present and future. In Insecticides of Plant Origin, 1st ed.; Arnason, J.T., Philogene, B.J.R., Morand, P., Eds.; America Chemical Society: Washington, DC, USA, 1989; pp. 1-10.

33. Barros, R.; Thuler, R.T.; Pereira, F.F. Técnica de criação de Plutella xylostella (L. 1758) (Lepidoptera: Yponomeutidae). In Técnicas de Criação de Pragas de Importância Agrícola, em Dietas Naturais, 1st ed.; Pratissoli, D., Ed.; Edufes: Vitória, Brasil, 2012; pp. 65-84. (In Portuguese)

34. Matias da Silva, R.; Fioratti, C.A.G.; Silva, G.B.; Cardoso, C.A.L.; Miranda, L.O.; Mauad, M.; Mussury, R.M. Antibiose do extrato foliar de Duguetia furfuracea sobre Plutella xylostella (Lepidoptera: Plutellidae). In Temas Atuais em Ecologia Comportamental e Interações, Anais do II BecInt_Behavioral Ecology and Interactions Symposium, 1st ed.; Calixto, E.S., Toreza-Silingardi, H.M., Eds.; Editora Composer: Uberlândia, MG, Brasil, 2017; pp. 52-69. (In Portuguese)

35. Duffey, S.S.; Isman, M.B. Inhibition of insect larval growth by phenolics in glandular trichomes of tomato leaves. Experientia 1981, 37, 575-576. [CrossRef]

36. Isman, M.B.; Duffey, S.S. Toxicity of tomato phenolic compounds to the fruitworm, Heliothis zea. Entomol. Exp. Appl. 1982, 31, 370-376. [CrossRef]

37. Klocke, J.A.; Kubo, I. Symposium: Insect Behavioral Ecology_'90: Defense of plants throügh regulation of insect feeding behavior. Fla. Entomol. 1991, 74, 18-23. [CrossRef]

38. Summers, C.B.; Felton, G.W. Pro oxidant effects of phenolic acids on the generalist herbivore Helicoverpa zea (Lepidoptera: Noctuidae): Potential mode of action for phenolic compounds in plant anti-herbivore chemistry. Insect Biochem. Mol. Biol. 1994, 24, 943-953. [CrossRef]

39. Pan, L.; Ren, L.; Chen, F.; Feng, Y.; Luo, Y. Antifeedant Activity of Ginkgo Biloba secondary metabolites against Hyphantria cunea Larvae: Mechanisms and applications. PLoS ONE 2016. [CrossRef] [PubMed]

40. Rani, P.U.; Ravibabu, M.V. Allelochemicals in castor (Ricinus communis L.) plants and their impact on pest larval feeding as anti-herbivore defensive. Allelopath. J. 2011, 27, 263-275.

41. Berenbaum, M. Adaptive significance of midgut $\mathrm{pH}$ in larval lepidoptera. Am. Nat. 1980, 115, $138-146$. [CrossRef]

42. Appel, H.M. Phenolics in ecological interactions: The importance of oxidation. J. Chem. Ecol. 1993, 19, 1521-1552. [CrossRef] [PubMed]

43. Santiago, R.; Malvar, R.A.; Baamonde, M.D.; Revilla, P.; Souto, X.C. Free phenols in maize pith and their relationship with resistance to Sesamia nonagrioides (Lepidoptera: Noctuidae) attack. J. Econ. Entomol. 2005, 98, 1349-1356. [CrossRef] [PubMed]

44. Arnason, J.T.; Gale, J.; Conilh de Beyssac, B.; Sen, A.; Miller, S.S.; Philogene, B.J.R.; Lambert, J.D.H.; Fulcher, R.G.; Serratos, A.; Mihm, J. Role of phenolics in resistance of maize grain to the stored grain insects, Prostephanus truncatus (Horn) and Sitophilus zeamais (Motsch.). J. Stored Prod. Res. 1992, 28, 119-126. [CrossRef]

45. Tavares, W.S.; Pereira, A.I.A.; Freitas, S.S.; Serrão, J.E.; Zanuncio, J.C. The chemical exploration of Dimorphandra mollis (Fabaceae) in Brazil, with emphasis on insecticidal response: A review. J. Sci. Ind. Res. 2014, 73, 465-468.

46. Piubelli, G.C.; Hoffmann-Campo, C.B.; Moscardi, F.; Miyakubo, S.H.; Oliveira, M.C.N. Baculovirus-resistant Anticarsia gemmatalis responds differently to dietary rutin. Entomol. Exp. Appl. 2006, 119, 53-60. [CrossRef]

47. Hoffmann-Campo, C.B.; Ramos Neto, J.A.; Oliveira, M.C.N.; Oliveira, L.J. Detrimental effect of rutin on Anticarsia gemmatalis. Pesqui. Agropecu. Bras. 2006, 41, 1453-1459. [CrossRef]

48. Stamp, N.E.; Skrobola, C.M. Failure to avoid rutin diets results in altered food utilization and reduced growth rate of Manduca sexta larvae. Entomol. Exp. Appl. 1993, 68, 127-142. [CrossRef]

49. Silva, T.R.F.B.; Almeida, A.C.S.; Moura, T.L.; Silva, A.R.; Freitas, S.S.; Jesus, F.G. Effect of the flavonoid rutin on the biology of Spodoptera frugiperda (Lepidoptera: Noctuidae). Acta Sci. Agron. 2016, 38, 165-170. [CrossRef]

50. Gazzoni, D.L.; Hulsmeyer, A.; Hoffmann-Campo, C.B. Efeito de diferentes doses de rutina e de quercetina na biologia de Anticarsia gemmatalis. Pesqui. Agropecu. Bras. 1997, 32, 673-681. (In Portuguese)

51. Tabashnik, B.E. Plant secondary compounds as oviposition deterrents for cabbage butterfly, Pieris rapae (Lepidoptera: Pieridae). J. Chem. Ecol. 1987, 13, 309-316. [CrossRef] [PubMed]

52. War, A.R.; Paulraj, M.G.; Ahmad, T.; Buhroo, A.A.; Hussain, B.; Ignacimuthu, S.; Sharma, H.C. Mechanisms of plant defense against insect herbivores. Plant Signal Behav. 2012, 7, 1306-1320. [CrossRef] [PubMed] 
53. Goławska, S.; Łukasik, I.; Kapusta, I.; Janda, B. Do the contents of luteolin, tricin, and chrysoeriol glycosides in Alfalfa (Medicago sativa L.) affect the behavior of Pea Aphid (Acyrthosiphon pisum)? Pol. J. Environ. Stud. 2012, 21, 1613-1619.

54. Simmonds, M.S.J. Flavonoid-insect interactions: Recent advances in our knowledge. Phytochemistry 2003, 64, 21-30. [CrossRef]

55. Goławska, S.; Sprawka, I.; Lukasik, I.; Golawski, A. Are naringenin and quercetin useful chemicals in pest-management strategies? J. Pest Sci. 2014, 87, 173-180. [CrossRef] [PubMed]

56. Kashiwagi, T.; Horibata, Y.; Mekuria, D.B.; Tebayashi, S.I.; Kim, C.S. Ovipositional deterrent in the sweet pepper, Capsicum annuum, at the Mature Stage against Liriomyza trifolii (Burgess). Biosci. Biotechnol. Biochem. 2005, 69, 1831-1835. [CrossRef] [PubMed]

57. Diaz Napal, G.N.; Defagó, M.T.; Valladares, G.R.; Palacios, S.M. Response of Epilachna paenulata to two flavonoids, pinocembrin and quercetin, in a comparative study. J. Chem. Ecol. 2010, 36, 898-904. [CrossRef] [PubMed]

58. Diaz Napal, G.N.; Palacios, S.M. Bioinsecticidal effect of the flavonoids pinocembrin and quercetin against Spodoptera frugiperda. J. Pest Sci. 2015, 88, 629-635. [CrossRef]

59. Tringali, C.; Spatafora, C.; Cali, V.; Simmonds, M.S.J. Antifeedant constituents from Fagara macrophylla. Fitoterapia 2001, 72, 538-543. [CrossRef]

(C) 2017 by the authors. Licensee MDPI, Basel, Switzerland. This article is an open access article distributed under the terms and conditions of the Creative Commons Attribution (CC BY) license (http://creativecommons.org/licenses/by/4.0/). 